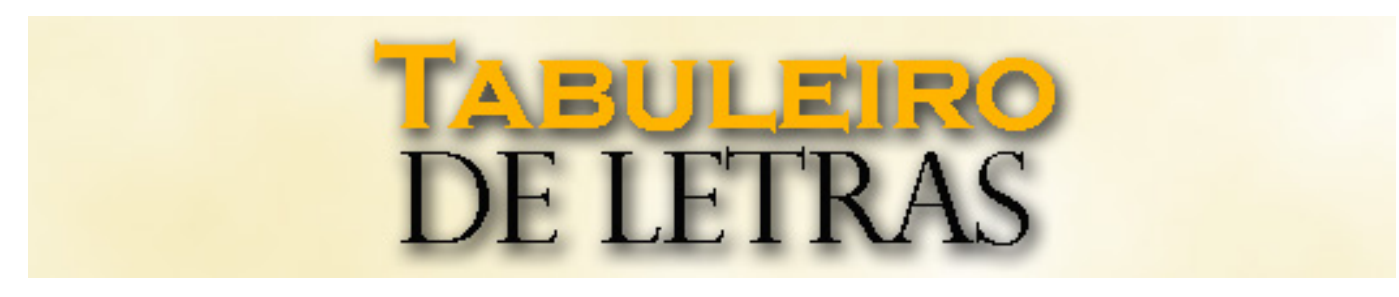

\title{
Antropofagia Literária: Um receituário clariceano em Laços de Família
}

\author{
Literary Anthropophagy: A Claricean cookbook in Family Ties
}

\author{
Cinthia Elizabet Otto Rolla Marques ${ }^{1}$
}

\begin{abstract}
RESUMO: A presença do alimento na literatura surge como um elemento simbólico de representação que, além de relatar cenas do ambiente familiar, encontros ou outras situações, permite que a personagem desencadeie ações, contribuindo para a sua caracterização física e psicológica. A personagem e o alimento relacionam-se mutuamente, e não apenas pelo fato de a figura humana (na Literatura, figura "de papel") precisar de se alimentar. O alimento exerce um papel semiótico, a personagem nutre-se não apenas de comida, alimenta-se também do outro, numa atuação antropofágica, para suprir a carência de sentimentos, quando se depara com a estranheza, com instintos primitivos ou com a necessidade de sobrevivência, numa investida para compreender o mundo ou a si mesma. Diante disso, propomos analisar os contos de Clarice Lispector $(1920$ - 1977), reunidos na obra Laços de Família (1960), com o intuito de identificar os tipos de representações dos alimentos e relacioná-los com a construção de identidade das personagens, assinalando o conceito de antropofagia clariceana e reconhecendo, dessa forma, as relações da comida com as personagens, no que toca ao título da obra: os laços de família.
\end{abstract}

Palavras-chave: Literatura; Alimentação; Clarice Lispector; Laços de Família.

\begin{abstract}
The presence of food in literature appears as a symbolic element of representation which, in addition to depicting family scenes, meetings or other situations, enables the characters to prompt actions and it adds to their physical and psychological portrayal. The characters and food interact mutually and not just through the human figure's - in Literature, a "paper" figure's - need to eat. Food plays a semiotic role in that a character feeds not just on food; he also feeds on the other in an anthropophagic action so as to make up for the lack of feelings, when faced with uneasiness, with primitive instincts, with the need for survival in an attempt to understand the world or oneself. In view of this, we intend to examine the stories of Clarice Lispector (1920 - 1977), collected in her book Family Ties (1960), trying to identify the food types represented and to connect them with the building of the characters' identity, by identifying the Claricean anthropophagic concept and thus acknowledge the food connections with the characters as far as the title of the work is concerned: the family ties.
\end{abstract}

Keywords: Literature; Food; Clarice Lispector; Family Ties.

Literatura e alimentação: o saber e o sabor

\footnotetext{
${ }^{1}$ Doutoranda em Patrimónios Alimentares: Culturas e Identidades - FLUC. E-mail: cinthia.otto@hotmail.com
} 
A literatura é um sistema de comunicação cujo suporte essencial é a palavra, a linguagem verbal. Como linguagem estética de comunicação, apresenta sentimentos, pensamentos, mundos possíveis e adquire novos aspetos de representação vinculados à realidade, alguns mais ou menos verossímeis. De acordo com Roland Barthes (1978), ao contrário da língua enquanto expressão social, na literatura está a liberdade da linguagem. Isso porque a comunicação literária não é prisioneira e fechada às estruturas linguísticas para enquadrar pensamentos, ela não nos obriga a dizer. A linguagem literária é livre para adquirir novos significados e representações nas palavras; é a linguagem com saber e com sabor ${ }^{2}$.

O homem, perpetuamente, obtém tudo o que o corpo exige para que lhe garanta a vida (BERRINI; MODESTO, 2014). O ato vital de alimentar-se sustenta valores simbólicos, faz parte de um sistema que implica atribuição de significados:

Todas as vezes que falo de comida, emito signos (linguísticos) que estão relacionados com um alimento ou com uma qualidade alimentar. [...] A linguagem suscita e exclui. A partir daí, o estilo gastronômico põe-nos perante toda uma série de questões. O que representar? Figurar? Projetar? Dizer? O que é desejar e falar ao mesmo tempo? (BARTHES, 2010, p. 21).

Para Maciel (2005), a culinária e as maneiras culturais codificadas e reconhecidas de se alimentar são elementos referenciais de uma identidade. Se os hábitos alimentares obedecem a um código simbólico, na literatura esse valor torna-se de extrema complexidade, tendo em vista que tanto a alimentação quanto a literatura são duas linguagens que por si só comunicam. No jogo híbrido em que o alimento é inserido na escrita literária, os termos alimentares podem ser observados como "uma espécie de operador universal do discurso" (BARTHES, 2010, p. 26). Na literatura a comida não é apenas um coadjuvante, conforme observa Pfeifer (2009). Introduzida no ambiente familiar, em reuniões ou encontros, é carregada de valores simbólicos que impulsionam a manifestação de identidades, hábitos e costumes, culturas, ideologias, patrimônios, relações pessoais, diferenças entre classes sociais e outros valores.

\footnotetext{
2 Para Barthes (1978), as palavras têm saber e sabor: na ordem culinária as coisas devem ter o gosto do que são, na ordem do saber é preciso o sal das palavras para que as coisas se tornem no que são. O gosto das palavras faz do saber algo úbere. Sobre a relação que une a linguagem e a gastronomia, na leitura que Barthes faz sobre Fisiologia do gosto, de Brillat-Savarin (2010, p. 10), o semiólogo francês questiona: "Não terão estes dois poderes a mesma origem? E, ainda mais, o mesmo aparelho, produtor ou apreciador gustativo (as bochechas, o palato, as fossas nasais) [...] que também produzem o bel canto? Comer, falar, cantar (é preciso acrescentar: beijar?) são operações que têm a sua origem no mesmo lugar do corpo: se cortarem a língua a alguém, deixa de haver gosto e fala".
} 
O universo alimentar em Clarice Lispector irrompe em palavras referentes não apenas aos próprios alimentos, mas também a objetos e utensílios, pratos, refeições, estados físicos e emocionais, atividades profissionais, partes do corpo humano, designações de índole poética ${ }^{3}$ e ambientes, "desencadeando uma série de outras ações importantes, seja para dar início a narrativas curtas, seja como recurso para a caracterização das personagens ou como um elemento descritivo em determinadas cenas" (PFEIFER, 2009, p. 139-140).

Laços de Família é lançado em São Paulo, no ano de 1960. O livro conta com a reunião de 13 contos $^{4}$ independentes, porém unificados pelo nome de um dos textos, usado como título da obra ${ }^{5}$. A temática da alimentação inserida no seio familiar mostra-nos que os laços que unem são os mesmos que aprisionam.

De acordo com Pfeifer (2009), a comida permite a interação das personagens e serve de pretexto para que o corpo social se manifeste e alcance o corpo físico ou intelectual. Em Laços de Família, as personagens nem sempre se alimentam de comida. $\mathrm{O}$ encontro entre opostos ocorre "numa tentativa de experimentar o não-eu como um objeto alheio ameaçador ou desejado para ser consumido e incorporado ou decifrado" (WILLIAMS, 1999, p. 29). Esse abalroamento com o mundo pode ser julgado, tanto como o universo interior quanto como o da linguagem.

O cânone usado para sistematizar a construção de identidades das personagens é a alimentação, pois é o arquétipo ideal de interação entre sujeito e mundo, porquanto pela boca é possível morder, destruir, devorar, mastigar, absorver. Acerca disso, Williams (1999) afirma que o apetite da fome e do saber precisam de ser saciados desde a infância, dado que "a criança só considera reais as coisas que consegue pôr na boca, porque os seus sentidos ainda não estão suficientemente desenvolvidos para experimentá-las de outra maneira” (WILLIAMS, 1999, p.

\footnotetext{
${ }^{3}$ A complexidade do mundo sob a "metáfora estranhada, oposta aos lugares-comuns, constitui um momento privilegiado na escritura de Clarice Lispector" (SÁ, 1979, p. 143). Destacamos alguns exemplos da imaginação poética de Lispector no decorrer da obra em análise com a semântica alimentar em enunciados metafóricos, como algo ilógico ou surreal: "Ai que quarto suculento"; "tudo ficou de carne"; "os filhos [...] uma coisa verdadeira e sumarenta"; "alimentava anonimamente a vida; "era um mundo de se comer com os dentes"; "A vida é horrível, disse-lhe baixo, faminta" (LISPECTOR, 2013).

${ }^{4}$ Segundo Carlos Mendes de Sousa (no posfácio de Laços de família), Lispector publicou em 1952 a obra Alguns contos com seis textos que foram incorporados em Laços de família: Mistério em São Cristóvão, Os laços de família, Começos de uma fortuna, Amor, Uma galinha, Um jantar. Dois outros contos, que depois foram sujeitos à reformulação, já haviam sido publicados no jornal $A$ Manhã, em 1946: $O$ crime e $O$ jantar. Na revista Senhor são publicados no ano de 1959: A menor mulher do mundo, O crime do professor de matemática, Feliz aniversário e Uma galinha; e em 1960, na mesma revista: A imitação da rosa e O búfalo. Em Julho de 1960 é publicado o volume Laços de família, pela editora Francisco Alves, reunindo os onze contos referidos e integrando mais dois: Devaneio e embriaguez de uma rapariga e Preciosidade (LISPECTOR, 2013, p. 149).

5 "É possível entrever, a partir dos contos que compõem Laços de família, um diálogo inesgotável, onde um conto se alimenta incessantemente do outro" (MANZO, 1997, p. 50).
} 
30). A comida, vista como um objeto de transição, estabelece limites entre o eu e o mundo, sendo importante na edificação da subjetividade e na aquisição de linguagem. Sendo assim, a boca é simbolicamente o lugar de incorporação e de onde emergem as palavras.

Os alimentos transitam nos planos das personagens, mas do que elas se alimentam ou precisam se alimentar é do outro. Essa incorporação é conduzida pelo conceito de antropofagia, porém não no ato canibalesco em si, mas como ato simbólico, corroborando a alteração da vida das figuras representadas.

Antropofagia literária

A obra de Clarice ${ }^{6}$ relaciona-se com o Movimento Modernista, em particular, com o quadro dialético localismo versus universalismo (ou primitivismo versus cosmopolitismo, de acordo com Sousa (2000), porém não se enquadra num movimento ou período específico da Literatura Brasileira, está numa zona fronteiriça, isto é, localizada num entre-lugar ou num nãolugar? ${ }^{7}$ Para o teórico, essa zona de fronteira "implica a exclusão de qualquer tipo de hierarquizações e propõe a instauração de um espaço de errância: não ser de nenhum lugar ou amplamente existir numa gravitação que é todos os lugares" (SOUSA, 2000, p. 33).

Ajustado à natureza do não-lugar, o itinerário clariceano é sobejamente considerado pela crítica como complexo, introspetivo e existencial (ALONSO, 2012). A escritora contempla os conflitos da alma humana ajustados na banalidade do ordinário, "as relações familiares ocupam um lugar privilegiado na obra de Lispector, bem representadas em seu cotidiano repressivo e alienador" (PERON, 2001, p. 108).

\footnotetext{
${ }^{6}$ Clarice Lispector nasceu em 10 de Dezembro de 1920 na aldeia ucraniana de Tchetchelnik. Foi para o Brasil com os pais, na fuga durante a Guerra Civil Russa. A família de emigrantes judeus chega em Maceió, no estado de Alagoas, no Brasil, em 1922 e muda-se para o Recife, em 1925. A mãe morre em 1930. Mudam-se para o Rio de Janeiro, em 1935. Clarice estuda hebraico e í́diche. Entra para o curso de Direito, em 1937 e, em 1940, começa a publicar na imprensa alguns contos. Trabalhou como repórter na Agência Nacional, o que permitiu que a escritora estivesse em contacto com personalidades da época, incluindo figuras da Literatura. Casou-se, em 1943, com um colega de curso, Maury Gurgel Valente, que ingressa na carreira diplomática. Nesse mesmo ano, Clarice obtém a nacionalidade brasileira e a carteira profissional de jornalismo. Clarice acompanha o marido para Belém, Nápoles, Berna, e regressa ao Rio em 1949. Vão ainda para Inglaterra e Washington. Em 1959, retorna definitivamente ao Brasil. Em 1966, vítima de um incêndio causado pelo cigarro que fumava antes de adormecer, Clarice reaprende a escrever, já que a parte mais afetada do seu corpo no acidente fora a mão direita. Morre em 9 de dezembro de 1977, vítima de câncer (LISPECTOR, 2013).

${ }^{7}$ A trajetória de Clarice pelas localidades que habitou, considerando também a do seu nascimento (Clarice era uma estrangeira), revela a problematização do território, do espaço, do instinto de nacionalidade e da visão não restrita de pertença num entre-lugar. $\mathrm{O}$ seu não-lugar na literatura também pode ser ponderado na entrevista concedida a Júlio Lerner, da TV Cultura, em 1977. Clarice, após ser questionada sobre o momento efetivo em que se assumiu como escritora, responde: "Eu nunca assumi”, assim justificando: "Eu não sou uma profissional, eu só escrevo quando eu quero. Eu sou uma amadora e faço questão de continuar sendo amadora. Profissional é aquele que tem uma obrigação consigo mesmo de escrever. Ou então com o outro, em relação ao outro. Agora eu faço questão de não ser uma profissional para manter minha liberdade".
} 
A mesa $^{8}$, espaço que congrega a família, torna-se uma experiência que reúne o desencontro, a separação e o aprisionamento. Verificamos a cena tradicional da família reunida à volta da mesa com imagens perturbadoras em que o pai assume a posição suprema de patriarca num pacto convivial, sancionando a hierarquização familiar em Começos de uma fortuna.

A avó, aniversariante e matriarca da família, ocupa a posição privilegiada da mesa ritualizada em Feliz aniversário. A data marca a reunião social e as "tensões dialéticas" (SOUSA; LISPECTOR, 2013, p. 144) na regra da conveniência entre algumas gerações, em que a refeição é sublinhada pelo vazio e pelo sufocamento.

No conto Mistério em São Cristóvão, o ambiente "ao redor da mesa" (LISPECTOR, 2013, p. 101) reflete, finalmente, o progresso da família. Contudo, algo acontece quando a filha mocinha surpreende pelo vidro da janela do quarto três mascarados que invadem o terreno para roubar jacintos e a família toda é desestruturada, todo o progresso frágil se desfaz.

Em Ojantar, a mesa é o cenário para um comedor solitário que é observado pelo outro9. A tensão é aferida na dicotomia entre o instintivo e o que é imposto, consubstanciado, assim, o “instinto de devoração" (SOUSA; LISPECTOR, 2013, p. 144).

Para Carlos Mendes de Sousa:

O caráter lúdico que preside ao acumular de diferentes experiências ficcionais, como as que lemos em Laços de família, não faz mais do que acentuar, por contraste, o desassossego que ressumbra de cada texto e que, [...] espelha o próprio processo, apropria a busca que é a escrita (SOUSA; LISPECTOR, 2013, p. 148).

A literatura de Clarice se alimenta da palavra (CARVALHO, 2012). Em A hora da estrela, obra publicada em 1977, temos a evidência sobre as tendências estilísticas de Lispector: “... tenho a tentação de usar termos suculentos: conheço adjetivos esplendorosos, carnudos substantivos e verbos tão esguios que atravessam agudos o ar em vias de ação, já que palavra é ação!" (WILLIAMS, 1999, p. 29).

No processo de construção identitária, as personagens clariceanas interagem com o meio no jogo entre "o sujeito narrador e a realidade" (NUNES, 1989, p. 83), centrado na tensão que

\footnotetext{
8 “[...] habitualmente as refeições surgiram na literatura a dar forma a grandes cenários conviviais e, muitas vezes, a partir deles [...] se pretender pôr a descoberto uma série de mazelas de que enferma a sociedade em questão" (SOUSA, 2000, p. 247). Clarice "encaixa uma forte tradição literária, dominantemente crítica, associada à mesa, às refeições e às palavras" (SOUSA, 2000, p. 248).

${ }^{9}$ Sobre o ponto de vista do voyeur, Barthes alega: "Quando quer apreender os efeitos voluptuosos da alimentação, é no corpo adverso que os vai procurar. Estes efeitos são, de algum modo, sinais que se captam numa interlocução em que se decifra o prazer do outro" (BARTHES, 2010, p. 11).
} 
rompe com o mundo por meio do estranhamento, do embate dos sentimentos ou da incompatibilidade entre pessoas. A esfera doméstica aprisiona as personagens num cotidiano falsamente inabalável e arredio que vai se diluindo quando ocorre algo de imprevisto e as fronteiras são suspensas.

O componente desmantelador da rotina de Ana, do conto Amor, é um cego que masca chicletes: "Foi então que olhou para o homem parado no ponto [...] Ele mastigava goma na escuridão. Sem sofrimento, com os olhos abertos" (LISPECTOR, 2013, p. 19). A imagem é desestabilizadora, capaz de romper com uma ordem que a protagonista tenta manter a todo custo. Depois do episódio, a personagem pondera o mundo ao seu redor com estranheza e dúvida. O que parecia ser insignificante acaba por descerrar um grande confronto interno e Ana sente a "vida cheia de náusea ${ }^{10}$ doce, até a boca" (LISPECTOR, 2013, p. 21).

Em $A$ imitação da rosa, Laura está inserida no ambiente doméstico, de ordem patriarcal, no comportamento e no convívio matrimonial. O desconforto da personagem, causado pela atenção antecipada no jantar que terá em convívio, provoca a ideia de similitude como preenchimento de "algo claro dentro dela" (LISPECTOR, 2013, p. 44):

Se o médico dissera: "Tome leite entre as refeições, nunca fique com o estômago vazio pois isso dá ansiedade [...] Para fundi-las numa só ela passara a usar um engenho: aquele copo de leite que terminara por ganhar um secreto poder, que tinha dentro de cada gole quase o gosto de uma palavra [...] (LISPECTOR, 2013, p. 33).

O conflito real instaura-se quando a personagem se depara com o jarro de flores da sua sala de estar. Com o gosto pela perfeição e pelo detalhe, a beleza extrema das rosas que havia comprado na feira a perturba e, apesar do mecanismo secreto do copo de leite, Laura agora funde-se com outro material: as rosas. A ameaça da perfeição das rosas provoca a sua assimilação com o intuito de absorver as suas qualidades.

Conforme Williams (1999), na prática antropofágica, concebida como absorção da força

\footnotetext{
${ }^{10}$ Benedito Nunes relaciona as tópicas da obra clariceana à filosofia existencialista, sobretudo a Sartre, pela conexão com a ideia de náusea como ponto de ruptura do sujeito e de neutralizadora do poder dos símbolos, "manifestando-se como um mal súbito e injustificável de que o corpo se apodera e do corpo que transmite a consciência $[\ldots]$ a náusea $[\ldots]$ revela, sob a forma de um fascínio da coisa, a contingência de um sujeito humano e o absurdo do ser que o circula. Esse estado produz a suspensão dos nexos teóricos e práticos que nos ligam ao mundo, e de injustificável que é, passa a constituir uma experiência do caráter injustificável da existência em geral" (NUNES, 1989, p. 117).
} 
e das habilidades do guerreiro consumido ${ }^{11}$, associada com a antropofagia psicanalítica, pode ser vista a incorporação (mental) de um objeto, assumindo o controle e, ao mesmo tempo, extraindo as suas essências valiosas ou úteis, fortalecendo a identidade da tribo ou do sujeito.

No conto que intitula a obra, Os laços de família, mãe e fillha sofrem uma colisão enquanto estavam dentro do táxi, no trânsito. O choque, violento e quase orgânico, faz com que a mãe habite na filha "de certa forma, impondo-lhe responsabilidades e marcando sua identidade" (PERON, 2001, p. 111), alterando as consequências na vida das duas personagens. Catarina pensa em dizer "mãe, eu sou sua filha. Ninguém mais pode te amar se não eu" (LISPECTOR, 2013, p. 87), e, nesse instante, sente "um gosto de sangue" (LISPECTOR, 2013, p. 87). Pode-se julgar que o embate resultou numa espécie de consumo do outro, conferindo a absorção da carne pelo gosto de sangue na boca:

Porque de fato sucedera alguma coisa, seria inútil esconder: Catarina fora lançada contra Severina, numa intimidade de corpo há muito esquecida, vinda do tempo em que se tem pai e mãe. Apesar de que nunca se haviam abraçado ou beijado. Do pai, sim. Catarina sempre fora mais amiga. Quando a mãe enchia-lhes os pratos obrigando-os a comer demais, os dois se olhavam piscando em cumplicidade e a mãe nem notava. Mas depois do choque no táxi e depois de se ajeitarem, não tinham o que falar (LISPECTOR, 2013, p. 8687).

$\mathrm{Na}$ tentativa de fuga, a galinha já exaurida põe um ovo. O pai e a filha do conto Uma galinha, comovidos com o feito, negam-se a comê-la. A mãe, apesar de nada entusiasta, poupa o almoço. A galinha passa a conviver como membro da família "até que um dia mataram-na, comeram-na e passaram-se anos" (LISPECTOR, 2013, p. 29). O ovo instantaneamente desperta no animal o instinto da maternidade. Apesar de ter gerado uma vida, não foi possível para a família poupar a galinha e fugir da origem devoradora da carne ${ }^{12}$.

Pfeifer (2009) nomeia tal episódio como "canibalismo por contingência" ao esclarecer que "o ato de comer carne não é em si fruto de uma necessidade específica de comer somente

\footnotetext{
${ }^{11}$ Para combater a fome ou como conduta ritualística praticada em algumas culturas medievais e em tribos indígenas, o canibalismo é o ato do indivíduo que come carne humana. Os índios tupinambás, no Brasil, praticavam o antropofagismo numa cerimônia canibal de guerra, para consumir a carne dos bravos guerreiros de tribos adversárias, a fim de incorporarem as qualidades como a coragem e a bravura do inimigo, sendo a maneira mais honorável de um combatente morrer (NUNES, 1990).

${ }^{12} \mathrm{Na}$ crónica Truculência, publicada em A descoberta do mundo, em 1984, Clarice afirma: "Quando penso na alegria voraz com que comemos galinha ao molho pardo, dou-me conta da nossa truculência. Eu, que seria incapaz de matar uma galinha [...] Nós somos canibais, é preciso não esquecer. É respeitar a violência que temos. E quem sabe, não comêssemos a galinha ao molho pardo, comeríamos gente com seu sangue. [...] A nossa vida é truculenta: nasce-se com sangue e com sangue corta-se a união que é o cordão umbilical”' (SOUSA, 2000, p. 239).
} 
carne humana, mas está submetida à precisão imperiosa de se alimentar de toda e qualquer substância digerível para sobreviver" (PFEIFER, 2009, p. 144).

A mitigação da fome desmedida ocorre em Preciosidade, que, "de forma muito simples, explora o universo alimentar e ilustra a fome e o desejo de comer que possui a personagem do conto" (PFEIFER, 2009, p. 143). A menina de quinze anos "comia como um centauro. A cara perto do prato, os cabelos quase na comida. - Magrinha, mas como devora, dizia a empregada esperta" (LISPECTOR, 2013, p. 78).

Um homem que "come com o corpo inteiro" (WILLIAMS, 1999, p. 32) devora pão, salada, bife, vinho tinto ${ }^{13}$ e, para sobremesa, um creme derretido. Os alimentos que ativam o grotesco e a animalidade do homem de $O$ jantar despertam no narrador a náusea: "Eu é que já comia devagar, um pouco nauseado sem saber por quê, participando também não sabia de quê" (LISPECTOR, 2013, p. 70). O narrador-voyeur rejeita a comida depois de testemunhar algo que não sabia: "Eu não podia mais, a carne no meu prato era crua, eu é que não podia mais. Porém ele - ele comia” (LISPECTOR, 2013, p. 71). Segundo Williams (1999), “o comentário pode ser considerado uma recusa do que o consumo parece ocasionar: uma reconstrução de identidade através da incorporação de "carne e sangue", uma imagem nitidamente antropófaga" (WILLIAMS, 1999, p. 32). O significado da comida e a voracidade no ato de comer é que dará lugar ao canibalismo e ao antropofagismo (PFEIFER, 2009). Ao mesmo tempo em que o observador se reconhece no outro, nega tornar-se o outro, assim como também renega a carne, o sangue, o seu eu canibal e a sua herança antropofágica: “eu não como. Não sou ainda esta potência, esta construção, esta ruína. Empurro o prato, rejeito a carne e seu sangue" (LISPECTOR, 2013, p. 73).

Influenciado por Montaigne ${ }^{14}$ e retomando o impulso antropofágico despertado por meio da pintura de Tarsila do Amaral $^{15}$ (1886 - 1973), o escritor Oswald de Andrade (1890 1954) escreve o Manifesto Antropófago, em 1928. O “manifesto lança a palavra "antropofagia”

\footnotetext{
${ }^{13}$ Sobre o vinho e a carne, em $O$ vinho e o leite e $O$ bife com batatas, o vinho adquire o valor simbólico "sob a sua forma vermelha [...] o sangue, líquido denso e vital" (BARTHES, 2001, p. 51) e o bife "participa da mesma mitologia sanguínea do vinho. É o coração da carne, é a carne no seu estado puro, e qualquer um que a consuma, assimila a força do touro" (BARTHES, 2001, p. 54).

${ }^{14}$ No capítulo 31, Dos canibais, do livro I de Ensaios, Montaigne (1998) relata os costumes das tribos tupinambás incluindo um ritual antropofágico. Após analisar essas sociedades, o ensaísta conclui que os bárbaros e selvagens, na verdade, são os europeus, pois a característica civilizadora corrompeu a sociedade, permitindo a promoção das guerras pautadas em disputas religiosas. Nas tribos a sociedade é equilibrada e harmoniosa, não há superioridade política e nem prática de servidão, não há nenhum metal e o grau de parentesco é universal, ligando toda a comunidade.

${ }^{15}$ Em 1928, a pintora Tarsila do Amaral presenteia o seu companheiro Oswald de Andrade com uma tela que até então não estava intitulada. A tela foi nomeada por Oswald de Abaporu, que do tupi-guarani significa o homem que come carne humana, o antropófago (GOTLIB, 2003).
} 
como pedra de escândalo [...] com a lembrança desagradável do canibalismo" (NUNES, 1990, p. 15). O movimento cultural consistia na deglutição da cultura estrangeira pelos modelos intermitentes de produção artística, absorvidos e incorporados na identidade cultural do Brasil:

Como símbolo da devoração, a Antropofagia é a um tempo metáfora, diagnóstico e terapêutica: metáfora orgânica, inspirada na cerimónia guerreira da imolação pelos tupis do inimigo valente apresado em combate, englobando tudo quanto deveríamos repudiar, assimilar e superar para a conquista de nossa autonomia intelectual (NUNES, 1990, p. 15).

Assim como a linguagem do manifesto é maioritariamente metafórica, a antropofagia em Clarice também é, uma vez que a autora tem raízes no modernismo e usa o conceito "de maneira eficaz como um método de neutralizar a ameaça do outro perigoso através da ingestão das suas qualidades" (WILLIAMS, 1999, p. 32).

No conto A menor mulher do mundo, Clarice apresenta-nos uma pigmeia proveniente do Congo Central, de uma cultura primitiva e vítima da crueldade pela prática canibal: “o grande risco para os escassos Likoualas está nos selvagens Bantos [...] Os Bantos os caçam em redes, como fazem com os macacos. E os comem. Assim: caçam-nos em redes e os comem" (LISPECTOR, 2013, p. 62). A situação de extrema sobrevivência coage no modo cultural da tribo. Moram em árvores altas "de onde as mulheres descem para cozinhar milho, moer mandioca e colher verduras; os homens, para caçar" (LISPECTOR, 2013, p. 62). Essa conjuntura afeta até mesmo no modo de comunicação, "pois mesmo a linguagem que a criança aprende é breve e simples, apenas o essencial. Os Likoualas usam poucos nomes, chamam as coisas por gestos e sons animais. Como avanço espiritual, têm um tambor" (LISPECTOR, 2013, p. 62). O devorar o outro é interpelado pelo contacto entre o explorador Marcel Petre e a selvagem Pequena Flor. Pela "necessidade imediata de ordem, e de dar nome ao que existe" (LISPECTOR, 2013, p. 61), analisa, classifica-a e ensina a língua.

Em contraposição a essa cultura primitiva, a civilização moderna é invocada por intermédio de uma página de um jornal, com a fotografia em tamanho real de Pequena Flor (45 centímetros), promovendo o contacto de duas culturas. Abre-se o espaço para que os leitores do jornal de domingo entrem na narrativa e reajam ao episódio. $\mathrm{O}$ inusitado retrato da pigmeia causa "aflição" numa personagem que se distancia do que tal ser lhe pode representar. Em outras personagens a recepção desperta o amor, o desejo de possuir alguém para si. É instaurado o confronto com o outro, que é "o que se mexe além de uma fronteira", provocando "questões que figuras de alteridade podem mobilizar no interior dos personagens, desestruturando suas 
rotinas e o modo de enxergar a si mesmos" (NOR, 2012, p. 75).

Uma leitora, enquanto enrolava os cabelos em frente ao espelho ${ }^{16}$, recorda-se de uma história que uma cozinheira lhe contara no tempo do orfanato. Trata-se de meninas que, não tendo bonecas, escondem da freira o corpo de uma das colegas morta para brincarem. Deramlhe banhos, comidinhas, beijos. A leitora e mãe

[...] considerou a cruel necessidade de amar. Considerou a malignidade de nosso desejo de ser feliz. Considerou a ferocidade com que queremos brincar. E o número de vezes em que mataremos por amor (LISPECTOR, 2013, p. 64).

A repercussão da imprensa revela eventualidades em que os sentimentos podem proferir nos núcleos familiares: “O leitor esbarra nos sentimentos estranhos, aquilo que tensamente está contido na palavra "amor": coisas nem sempre imediatamente percetíveis, ou dificilmente verbalizadas" (SOUSA; LISPECTOR, 2013, p. 148).

Ana, a personagem de Amor, depois do choque com o cego, passa por um momento epifânico e perde-se no retorno a casa. Assim que regressa encontra-se com o filho e

[...] apertou-o com força, com espanto. Protegia-se trémula. Porque a vida era periclitante. Ela amava o mundo, amava o que fora criado - amava com nojo. Do mesmo modo como sempre fora fascinada pelas ostras, com aquele vago sentimento de asco que a aproximação da verdade lhe provocava, avisando-a. Abraçou o filho, quase a ponto de machucá-lo. [...] Sentia as costelas delicadas da criança entre os braços, ouviu seu choro assustado. Mamãe, chamou o menino. [...] A criança mal sentiu o abraço se afrouxar, escapou e correu até a porta do quarto, de onde olhou-a mais segura. Era o pior olhar que jamais recebera (LISPECTOR, 2013, p. 23).

A mãe representa com força o amor que sente pelo filho, ao ponto de o submergir numa prática antropofágica de assimilação do outro; aliás, "vários personagens de Clarice sentem um desejo forte que a autora descreve em termos de incorporação e fusão" (WILLIAMS, 1999, p. 29). No entanto, evitam a exteriorização do afeto pois "tais elementos lhes aparecem como risco de desestruturação completa” (NOR, 2012, p. 86).

\footnotetext{
${ }^{16}$ São recorrentes em Laços de família o uso de espelhos pelas personagens ou o contacto com o próprio reflexo. Como se um olho que espreita pelo buraco da fechadura se depara com um outro olho que espreita pelo lado oposto, o contacto com o espelho como objeto identitário pode ser chocante, gelatinoso e violento. Conforme Gabriela Ruggiero Nor, a atenção do olhar consiste no ver e ser visto, uma experiência do ser. O espelho surge como mediador do desdobramento da consciência de si, do duplo, refletido da realidade interior, assinala o confronto com a imagem do próprio corpo estranhado, que parece servir de veículo a forças obscuras, local de onde a identidade narcisista se transforma em alteridade (NOR, 2012, p. 10).
} 
Maria Quitéria, a personagem de origem portuguesa que vive no Rio de Janeiro, transita entre as palavras que intitulam o conto - Devaneio e embriaguez duma rapariga -, enquanto vive num estado de incorporação pelo vinho - objeto este propiciador da epifania - concedendo a fuga da habitual rotina de mãe, esposa e dona de casa, que, segundo Nor (2012), é conduzida a uma dimensão interior. $\mathrm{O}$ estado de inebriamento viabiliza a desordem e o desvirtuamento das fronteiras, em que até mesmo o discurso da protagonista é confuso quando se refere a si própria em "eu-tu". A mulher sente dificuldades em refletir sobre si mesma cuja ocorrência possibilita verificar também as dificuldades no âmbito familiar. O conto encerra-se com o sentimento de amor: "então a grosseria explodiu-lhe em súbito amor: cadela, disse a rir" (LISPECTOR, 2013, p. 16).

Para Nunes (1989), o papel que os animais desempenham na estética clariceana reflete a busca da autenticidade humana. Sousa (2000) aponta os instintos básicos do animal como a força física e a devoração. Ao discorrer sobre a tensão das emoções em $O$ crime do professor de matemática, o cão é o objeto absoluto do aprendizado de amor pleno. Já em $O$ búfalo, uma figura feminina vai ao jardim zoológico à procura de uma nova inspiração, pois o marido não a ama e ela pretende retribuir: "Onde aprender a odiar para não morrer de amor?" (LISPECTOR, 2013, p. 119). Nunes destaca que

[...] esses sentimentos fortes e violentos, que polarizam a vida afetiva em constante metamorfose, estão sujeitos a buscas e transformações. [...] o amor traz sempre uma "vontade de ódio", e o ódio, uma vontade de amor (NUNES, 1989, p. 103).

Com o estômago contraído "em cólica de fome e vontade de matar" (LISPECTOR, 2013, p. 117), já com o céu que "rondava no estômago vazio" (LISPECTOR, 2013, p. 118), ocorre o crucial e epifânico ${ }^{17}$ encontro com o búfalo. Com o coração batendo "oco entre o estômago e os intestinos" (LISPECTOR, 2013, p. 121), a personagem entrega-se: "Eu te odeio, disse implorando amor ao búfalo" (LISPECTOR, 2013, p. 122), "e os olhos do búfalo, os olhos

\footnotetext{
${ }^{17}$ Geralmente deparamo-nos em Laços de família com momentos de epifania, quando uma personagem se esbarra com algo inesperado e a vida fica suspensa. A epifania (o termo epifania vem do grego "epi"=sobre e "phaino"= aparecer, brilhar; epipháneia "significa manifestação, aparição" (SÁ, 1979, p. 168), no plano místico-religioso, "é um conceito central do mundo hebreu, que mostra somente algumas coincidências exteriores com fenómenos semelhantes do mundo pagão ambiente" (SÁ, 1979, p. 168). Segundo a autora, a epifania constitui uma realidade complexa, percetível aos sentidos. Pela invenção verbal incorpora-se a imaginação epifânica, portanto a epifanialinguagem é revelada na própria palavra. Clarice utiliza o processo epifânico considerado como "crítico" com o vislumbre da crise de identidade, em que a personagem não se reconhece, e com momentos de transfigurações do banal em beleza que "muitas vezes, como marca sensível da epifania crítica, surge o enjoo, a náusea. A transfiguração não é radiosa, mas se faz no sentido do mole, do engordurado e demoníaco" (SÁ, 1979, p. 199).
} 
olharam seus olhos. E uma palidez tão funda foi trocada que a mulher se entorpeceu dormente" (LISPECTOR, 2013, p. 122). O ato de incorporação é realizado por meio da penetrante troca de olhares entre a mulher e o animal: “[...] entrando cada vez mais fundo dentro daqueles olhos que sem pressa fitava [...] presa ao mútuo assassinato. Em então lenta vertigem que antes do corpo baquear macio a mulher viu o céu inteiro e um búfalo" (LISPECTOR, 2013, p. 123).

Não há a afirmação sobre a morte da mulher de $O$ búfalo. Contudo, devemos considerar que a personagem busca uma imagem de si. A representação simbólica do animal expressa a concepção que o ser humano tem de si mesmo e, em todos os contos de Laços de família, de acordo com Sousa (2000), de modo voluntário ou involuntário, as personagens questionam a identidade do ser.

\section{Considerações Finais}

Diante de tais premissas, verificamos que os sentimentos suscitados no centro familiar e no cotidiano, em contacto com o momento de epifania, despertam o que há de primordial e de destrutivo no ser humano. As famílias, inseridas num contexto social, acabam sendo afetadas por situações em que o sentido de civilizado vem a ser defrontado com o instinto primitivo do homem, fazendo com que os laços afetivos, em vez de prometerem segurança, sejam deturpados. Nessas situações incluem também os afetos que, nas "relações com os outros e com as próprias coisas" (NUNES, 1989, p. 101), não são possíveis de serem pensados, $\operatorname{ditos}^{18}$ ou sentidos e, por medo da experiência de transitar entre as fronteiras, são aniquilados. Assim é feita a concepção do mundo, segundo Nunes (1989); assim é feita a vida, é periclitante, como diz Lispector.

O abalo desmantelador afeta a linguagem do indivíduo e, para recompor o seu posicionamento no mundo, desperta em si a necessidade de algo. É preciso uma fonte, para que o indivíduo ultrapasse essa situação, que ele consiga sobreviver, redefinir a sua identidade e buscar as mais coerentes e adequadas palavras para se comunicar. Em se tratando do uso da linguagem, não há um alimento específico que forneça o nutriente psicológico ou emocional de que a personagem tanto necessita. Esse alimento não concreto, não nomeado e sem medida acaba por suscitar um flagelo na escrita: a problemática da forma. Aqui se insere a antropofagia

\footnotetext{
${ }^{18}$ Nunes afirma que as palavras têm um imenso poder, capaz de formar o mundo e de aprisionar, ao erguer obstáculos frente à liberdade: "As palavras amortalham os sentimentos que elas próprias partejam. O dizer modifica o sentir" (NUNES, 1989, p. 103).
} 
como método de supressão dessas lacunas em que ocorre a oposição entre o primitivo e civilizado. Esse instinto primordial é reconfigurado na literatura na busca da essência do outro, num ato transcendental e purificador, como se fosse uma prática catártica usada para suprir a natureza do ser.

O desconhecido é aquilo ou aquele que habita além da fronteira do corpo do sujeito. Para tornar-se conhecido, é preciso incorporá-lo. O estranhamento propicia a abertura, para que se busque fora do eu o que o corpo carece. Dessa forma ocorre a transição entre fronteiras. $\mathrm{O}$ trânsito entre barreiras, para além da fronteira do indivíduo, ocorre procedente do alimento. Ao provar o gosto do alimento (o corpo ou o objeto alheio) e incorporá-lo, os conhecimentos são fortalecidos, a identidade e a língua são desenvolvidas, além de que o próprio alimento ensina a transitar entre as fronteiras.

Quando ocorre o consumo do outro, o meu eu não é dizimado, ele funde-se na comunhão “dos restos de todos os outros que já devorou” (WILLIAMS, 1999, p. 30). Apesar dos penosos conflitos a que as personagens ficam sujeitadas, elas "regressam às suas condições anteriores" (SOUSA; LISPECTOR, 2013, p. 138), mas agora assimiladas pelo transcendental momento transformador, pois a ultrapassagem de fronteiras permite que o desconhecido venha a ser apreendido e algo no interior do sujeito seja incorporado. É uma maneira de "suportar o mundo exterior através de uma fusão" (WILLIAMS, 1999, p. 29), passa-se do "olhar" para o "ver" e o desvelar do mundo confere o autoconhecimento.

As palavras e os alimentos transitam no mesmo território: a boca. O local por onde se come e por onde se fala invoca dois mundos, o exterior e o interior. As palavras e os alimentos, portanto, irrompem a barreira fronteiriça, pertencendo a nenhum lugar e, simultaneamente, a todos os lugares. O eu também é local e ao mesmo tempo universal, pois a partir do momento que se sai do seu limite, passa a ser global, completo.

A linguagem é o recurso de absorção do outro por meio da representação. Também no plano epistemológico, parafraseando Sá (1979), para que o texto, o conhecimento e a comunicação existam, o eu precisa do outro do mesmo modo que o emissor precisa do recetor e que o escritor precisa do leitor. A antropofagia clariceana, além de nos instruir acerca da necessidade do espírito canibal, de ficcionar a transição de uma situação experiencial negativa em valor positivo para a vida (CARVALHO, 2012), serve como mecanismo estético que permite pensar sobre o outro, ao passo que a alimentação é um recurso linguístico sujeito à interpretação. Ao falar em comida, instaura-se esse universo que nem sempre é utilizado para 
falar sobre ele mesmo, mas, com a liberdade artística que é inerente à literatura, dedica-se ao tratamento de inúmeras temáticas.

\section{Referências}

ALONSO, Mariângela. Mulheres e baratas: Clarice Lispector na imprensa feminina. Campinas, SP: III Simpósio Nacional Discurso, Identidade e Sociedade, 2012. Disponível em: http://www.iel.unicamp.br/sidis/anais/pdf/ALONSO_MARIANGELA.pdf Acesso em: maio 2016.

BARTHES, Roland. Aula. Trad. Leyla Perrone-Moisés. São Paulo: Cultrix, 1978. Disponível em:

http://disciplinas.stoa.usp.br/pluginfile.php/160637/mod_resource/content/1/BARTHES_Rola nd_-_Aula.pdf Acesso em: maio 2016.

. Leitura de Brillat-Savarin. In BRILLAT-SAVARIN, Jean Anthelme. Fisiologia do gosto. Trad. Rita Ferreira e José Cláudio. Lisboa: Relógio D’Água, 2010, p. 9-27.

. Mitologias. Trad. Rita Buongermino e Pedro de Souza. Rio de Janeiro: Bertrand, 2001.

BERRINI, Beatriz; MODESTO, Maria de Lourdes. Comer e beber com Eça de Queiroz. Lisboa: Fundação Eça de Queiroz e Alêtheia Editores, 2014.

CARVALHO, Silvânia Cápua. A sensibilidade clariceana de narrar o cotidiano. In: $3^{\circ}$ Colóquio do Grupo de Estudos Literários Contemporâneos: um cosmopolitismo nos trópicos e 100 anos de Afrânio Coutinho: A crítica literária no Brasil. Anais. Feira de Santana: Universidade Estadual de Feira de Santana, 2012, p. 107-116. Disponível em: http://www2.uefs.br/dla/romantismoliteratura/coloquiogrupodeestudos2011/anais/3coloq.anai s.107-116.pdf Acesso em: maio e junho 2016.

FUNDAÇÃO Padre Anchieta. Tv-2. Panorama com Clarice Lispector. São Paulo: TV Cultura, 1977. 28m32s. Disponível em: https://www.youtube.com/watch?v=ohHP112EVnU Acesso em: maio 2016.

GOTLIB, Nadia Battella. Tarsila do Amaral, a modernista. São Paulo: Senac, 2003.

LISPECTOR, Clarice. Laços de Família. Lisboa: Cotovia, 2013.

MACIEL, M. E. Olhares antropológicos sobre a alimentação: Identidade Cultural e Alimentação. In: CANESQUI, Ana Maria e GARCIA, Rosa Wanda Diez (Org.). Antropologia e nutrição: um diálogo possível. Rio de Janeiro: FIOCRUZ, 2005, pp. 49-55. Disponível em: http://books.scielo.org/id/v6rkd/pdf/canesqui-9788575413876-03.pdf Acesso em: maio 2016.

MANZO, Lícia. Era uma vez: Eu - A não-ficção na obra de Clarice Lispector. Curitiba: Secretaria do Estado da Cultura, 1997. 
MONTAIGNE. Michel de. Dos canibais. In: . Ensaios. Trad. ROMÃO, Rui Bertrand. Lisboa: Relógio D’Água, 1998, p. 131-144.

NUNES, Benedito. O drama da linguagem: uma leitura de Clarice Lispector. São Paulo: Ática, 1989.

A antropofagia ao alcance de todos. In: ANDRADE, Oswald de. A utopia antropofágica. São Paulo: Globo e Secretaria do Estado da Cultura, 1990.

NOR, Gabriela Ruggiero. Imagens no espelho em Clarice Lispector: entre reflexos e passagens. 2012. 196 f. Dissertação (Mestrado em Literatura Brasileira). São Paulo: Faculdade de Filosofia, Letras e Ciências Humanas, Universidade de São Paulo, 2012. Disponível em: http://www.teses.usp.br/teses/disponiveis/8/8149/tde-29102012-112144/pt-br.php Acesso em: maio 2016.

PERON. Paula Regina. Uma análise do conto "Os laços de família” de Clarice Lispector, segundo o recorte e corte da Psicanálise da família. Os Laços entre Literatura e Psicanálise. In: Interações, vol. VI, n. 12. São Paulo: Universidade São Marcos, 2001, pp. 107-116. Disponível em: http://www.redalyc.org/pdf/354/35461206.pdf Acesso em: maio 2016.

PFEIFER, Caroline. Clarice Lispector e a voracidade. In: Outra travessia, n. 9. Florianópolis: Universidade Federal de Santa Catarina, 2009, pp. 138-150. Disponível em: https://periodicos.ufsc.br/index.php/Outra/article/view/2176-8522.2009n9p139/20526 Acesso em: maio 2016.

SÁ, Olga de. A escritura de Clarice Lispector. Petrópolis: Vozes, 1979.

SOUSA, Carlos Mendes de. Clarice Lispector: Figuras da Escrita. Braga: Universidade do Minho, 2000.

. Posfácio. In: LISPECTOR, Clarice. Laços de Família. Lisboa: Cotovia, 2013.

WILLIAMS, Claire. Decifra-me ou devoro-te: dimensões de gastronomia ou do gustativo em Clarice Lispector. In: Terceira Margem, n. 2. Porto: Faculdade de Letras da Universidade do Porto, 1999, pp. 29-35. Disponível em: http://ler.letras.up.pt/uploads/ficheiros/7380.pdf Acesso em: maio e junho 2016. 